\title{
The Effect of Certification and Competency towards Teachers Quality in MAN 3 High School Tangerang, Indonesia
}

\author{
Zaharah* $^{*}$ \\ University of Muhammadiyah Tangerang \\ *Corresponding author: chibro9699@yahoo.com \\ Received March 18, 2014; Revised April 15, 2014; Accepted April 24, 2014
}

\begin{abstract}
The study of the effect of certification and competency towards teacher quality has been carried out in MAN 3 High School of Tangerang, Perum Islamic Karawaci Tangerang City District, Banten Province, Indonesia, from 2013 until 2014. The main objective of this study was to determine (1) whether there is a difference in the quality of teachers before and after certification, and (2) to the extent of which the influence of certification benefit on teacher performance. The method used in this study was survey that was limited to the survey of sample. In determining the size of the sample of those teachers who had been certified, the sampling technique used was simple random technique. Descriptive quantitative by using figures and calculations with statistical methods was used on this study. The data then classified and categorized using certain tables. Simple regression analysis, two-way analysis variance with the fulfillment of the test homogeneity variance analysis, and test validity and reliability were used for data analysis. The results showed that (1) all data had met the prerequisite test analysis based on the results of test normality and linearity (2) There were positive and significant effect for certification on teacher quality.
\end{abstract}

Keywords: certification, competency, teacher quality, MAN 3Tangerang, Indonesia

Cite This Article: Zaharah, "The Effect of Certification and Competency towards Teachers Quality in MAN 3 High School Tangerang, Indonesia.” American Journal of Educational Research, vol. 2, no. 5 (2014): 267-271. doi: 10.12691/education-2-5-5.

\section{Introduction}

Recent federal legislation has put increased pressure on school systems to staff all classrooms with "highly qualified" teachers and has focused attention on the importance of teacher quality for improving outcomes for students in kindergarten through twelfth grade (K-12). Prescriptions for improving the quality of the K-12 teacher workforce focus on instructional practices and/or market incentives. Those emphasizing instructional practices point to the need for improvements in the quality and alignment of pre-service programs and in-service professional development, with state and national standards for K-12 course content and pedagogy. Those that focus more heavily on labor markets for teachers argue for the need to increase incentives to attract and retain high-quality teachers and to encourage teachers to strive continually to increase the performance of their students [1].

A growing body of research shows that the quality of the teacher in the classroom is the most important schooling factor predicting student outcomes $[2,3,4,5,6]$. Furthermore, the impact of having a high-quality teacher can be profound. [7], for instance, finds that, all else equal, a student with a very high quality teacher will achieve a learning gain of 1.5 grade level equivalents, while a student with a low-quality teacher achieves a gain of only 0.5 grade level equivalents. Thus, the quality of a teacher can make the difference of a full year's learning growth.

While researchers tend to agree that teacher quality is an important determining factor in influencing student outcomes, there is little consensus about the relationship between specific teacher credentials (experience and degree level) and characteristics (age, race and ethnicity), and teacher effectiveness. Certain teacher characteristics - a subject-specific master's degree, for example seem to matter in certain contexts (high school math), but not in others. More to the point, only a small percentage of what makes teachers successful in the classroom is associated with characteristics such as degree and experience levels, and certification status [8,9]. In other words, teachers clearly matter, but teacher quality is not strongly related to observed teacher characteristics. There is a seeming contradiction between the fact that teachers have a large impact on student achievement but specific teacher attributes are not consistently found to directly impact student achievement. This may be credited to the fact that the attributes that actually make teachers successful in the classroom (e.g., enthusiasm and ability to convey knowledge) are not strongly related to the teacher attributes typically measured in education productivity studies [10].

Education has been shown to be key to economic growth [11] and to the determination of earnings of 
individuals within a society [12]. Because it affects society so directly and dramatically, the education industry is often singled out for scrutiny at all levels. It is frequently claimed that performance in education is hampered by a failure to provide both appropriate incentives and professional allowance. Performancerelated pay for teachers is being introduced in Indonesia and it amidst much controversy and opposition from teachers and society alike. The rationale for these programs is the notion that incentive pay, or used to said professional allowance, may motivate teachers to improve their performance. However, there is little study of the effect of changes in teachers' performance in schools.

Much of the recent interest in educational reform has focused on the use of monetary incentives to motivate teachers. Unfortunately, research on teacher compensation and reward preferences provides only limited support for the premise that the availability of increased monetary rewards can effectively motivate teachers to improve their performance. Indeed, many researchers feel that teachers are motivated more by the content and process of their work than by the opportunity for extra compensation $[13,14,15]$.

This study was carried out in order answer the questions of (1) whether there is a difference in the quality of teachers before and after certification, and (2) to the extent of which the influence of certification benefit on teacher performance.

\section{Materials and Methods}

\subsection{Study Site}

The study was conducted in MAN (High School) 2 Tangerang, Perum Islamic Karawaci Tangerang City District, Banten Province, Indonesia, from 2013 until January 2014. Thirty (30) teachers whose received certifications were chose for sample population.

\subsection{Goal and Purpose of Study}

This study starts from the need to identify the method, materials and technique that can contribute for new knowledge of certification and competency towards teacher quality in MAN 3 High School Tangerang. Therefore, the important goal from this study is supported by two purposes : 1) to investigate the certification might effect the quality of teachers in MAN 3 High School Tangerang, 2) to investigate the competency might effect the quality of teachers in MAN 3 High School Tangerang, and 3) to investigate both certification and competency might effect the quality of teachers in MAN 3 High School Tangerang as shown in Figure 1.

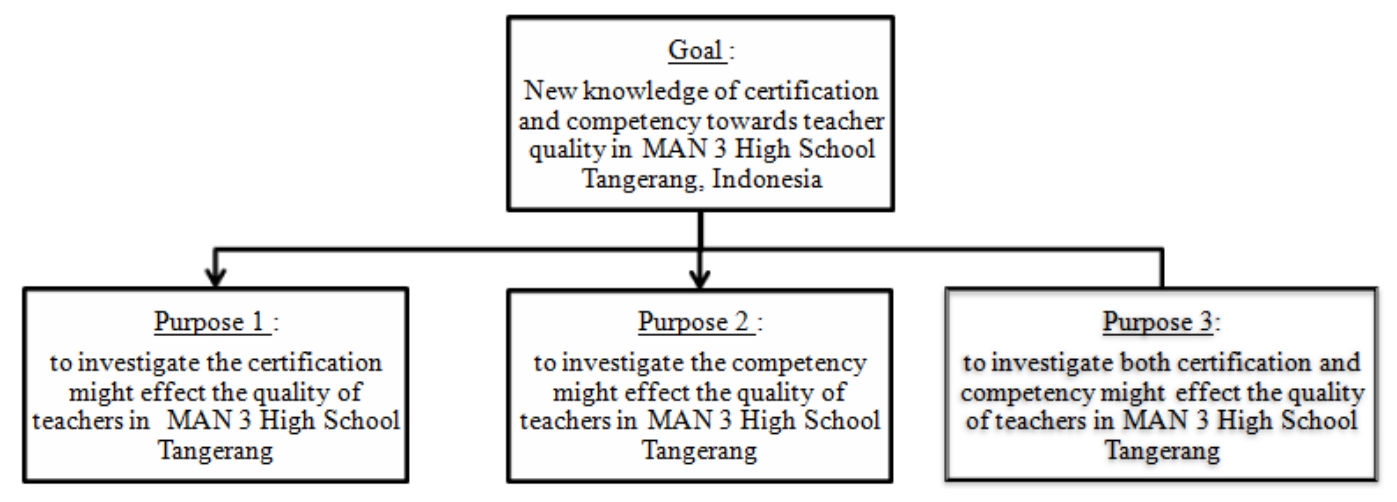

Figure 1. Goal and Purpose of Study

\subsection{Research Constellation and Hypothesis}

The study was conducted by using descriptive quantitative by using figures and calculations with statistical methods. The data then classified and categorized using certain tables. Simple regression analysis, two-way analysis variance with the fulfillment of the test homogeneity variance analysis, and test validity and reliability were used for data analysis. The constellation research is shown in Figure 2.

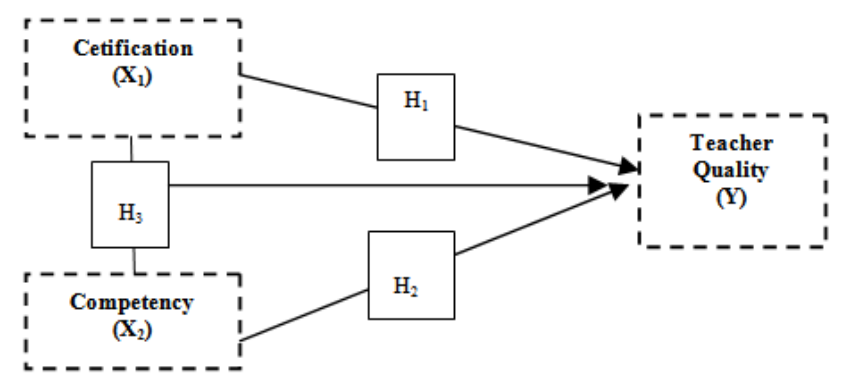

Figure 2. Research Constellation and Hypothesis
There were three hypothesis occurred from this study regarding effect of two variables $\mathrm{X}$ to one variable $\mathrm{Y}$. The hypothesis were :

1. First Hypothesis

$\mathrm{H}_{0}: \beta_{1} \geq 0$

Certification has effect towards teacher quality.

$\mathrm{H}_{1}: \beta_{1}<0$

Certification has no effect towards teacher quality.

2. Second Hypothesis

$\mathrm{H}_{0}: \beta_{2} \geq 0$

Competency has effect towards teacher quality.

$\mathrm{H}_{1}: \beta_{2}<0$

Competency has no effect towards teacher quality.

3. Third Hypothesis

$\mathrm{H}_{0}: \beta_{3} \geq 0$

Both certification and competency have effect towards teacher quality.

$\mathrm{H}_{1}: \beta_{3}<0$

Both certification and competency have no effect towards teacher quality. 


\subsection{Data Collection}

There were two types for data collection, questionare using Linkert standard and interview. Questionare was designed for interval 1 to 5 , with the highest score was 5 and the lowest score was 1 . The scoring data is shows on Table 1.

Table 1. Scoring Data

\begin{tabular}{llccl}
\hline No & Answer & Code & Score & Quality \\
\hline 1 & Strongly agree & SS & 5 & Perfect \\
2 & Agree & S & 4 & Above average \\
3 & Neutral & N & 3 & Average \\
4 & Not agree & TS & 2 & Below average \\
5 & Strongly not agree & STS & 1 & No satisfaction \\
\hline
\end{tabular}

\section{Result}

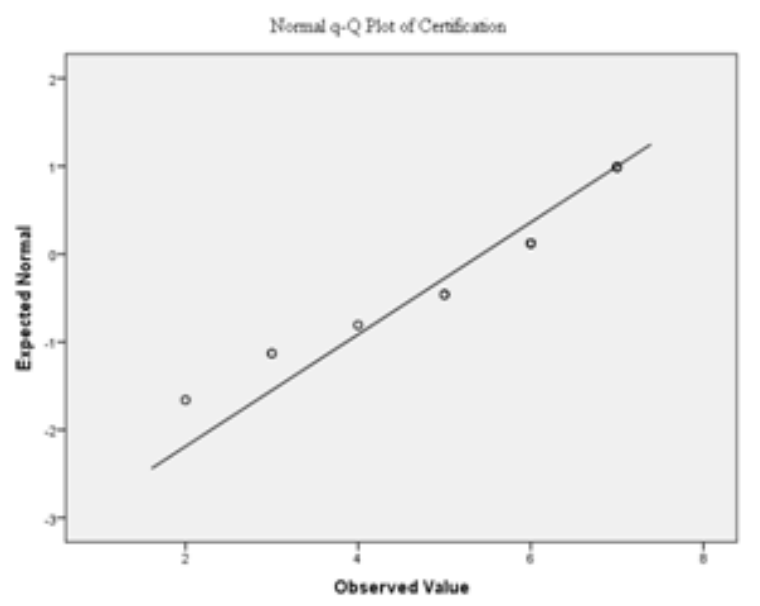

\subsection{Test of Normality}

Test of normality was done in order to determined wheather the data distribution were normal or were not normal. One sample Kolmogorov-Smirnov Test was used for this test. The result test of normality is shows in Table 2.

Table 2. Test of Normality

\begin{tabular}{lcccccc}
\hline \multirow{2}{*}{ Variable } & \multicolumn{3}{c}{ Kolmogorov-Smirnov } & \multicolumn{3}{c}{ Shapiro-Wilk } \\
\cline { 2 - 7 } & Statistic & df & Sig. & Statistic & df & Sig. \\
\hline Certification & 0.241 & 30 & 0.00 & 0.852 & 30 & 0.01 \\
Competency & 0.253 & 30 & 0.00 & 0.777 & 30 & 0.00 \\
Teacher quality & 0.224 & 30 & 0.01 & 0.747 & 30 & 0.00 \\
\hline
\end{tabular}

a. Lilliefors Significance Correction

Based on test of normality, it was found that certification had p-value of 0.00 , competency had p-value of 0.00 , and teacher quality had p-value of 0.01 . All variables had significance p-value below of 0.05 , thus the data had normal distribution.

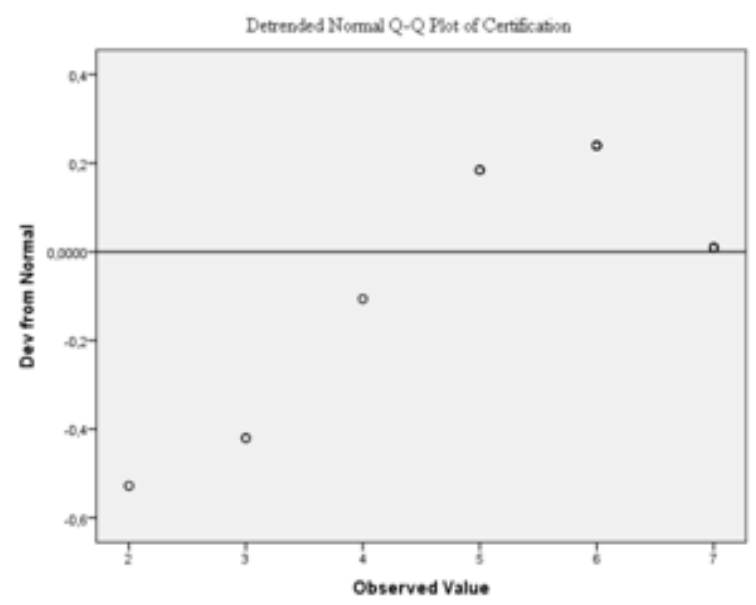

Figure 3. Normal Q-Q Plot and Detrended Normal Q-Q Plot of Certification

\subsection{Test of Linearity}

Test of linearity was done in order to investigate the correlation of dependent variable and independent variable, whether both variables had linearity or no linearity. Deviation from linearity was used on this test. The result test of linearity is shows in Table 3 and Table 4.

Table 3. ANOVA for test of linearity of certification

\begin{tabular}{ccccccc}
\hline & & $\begin{array}{c}\text { Sum of } \\
\text { square }\end{array}$ & df & $\begin{array}{c}\text { Mean } \\
\text { square }\end{array}$ & F. & Sig. \\
\hline \multirow{4}{*}{$\begin{array}{c}\text { Between } \\
\text { Groups }\end{array}$} & $\begin{array}{c}\text { Linearity } \\
\text { Deviation from } \\
\text { Linearity }\end{array}$ & 540.522 & 5 & 108.104 & 0.889 & 0.504 \\
& 0.135 & 1 & 0.135 & 0.001 & 0.974 \\
Within Groups & 2919.388 & 4 & 135.097 & 1.110 & 0.375 \\
& Total & 3460.300 & 29 & & & \\
\hline
\end{tabular}

Deviation from linearity for teacher quality, which is affected by certification, had significance 0.974 . This value was higher than 0.05 and can be concluded that correlation between certification and teacher performance had linearity. Meanwhile, teacher quality, which is affected by competency, had significance 0.09 . This value was higher than 0.05 and can be concluded that correlation between competency and teacher quality had linearity.
Table 4. ANOVA for test of linearity of competency

\begin{tabular}{|c|c|c|c|c|c|}
\hline & & $\begin{array}{l}\text { Sum of } \\
\text { Squares }\end{array}$ & df & $\begin{array}{c}\text { Mean } \\
\text { Square }\end{array}$ & F Sig. \\
\hline \multirow{3}{*}{$\begin{array}{c}\text { Between } \\
\text { Groups }\end{array}$} & (Combined) & 2629.33 & 10 & 262.933 & 6.010 .00 \\
\hline & Linearity & 1200.24 & 1 & 1200.24 & 27.440 .00 \\
\hline & $\begin{array}{l}\text { Deviation from } \\
\text { Linearity }\end{array}$ & 1429.08 & 9 & 158.78 & 3.630 .09 \\
\hline \multicolumn{2}{|c|}{ Within Groups } & 830.97 & 19 & 43.73 & \\
\hline \multicolumn{2}{|r|}{ Total } & 3460.30 & 29 & & \\
\hline
\end{tabular}

\subsection{The Effect of Certification towards Teacher Quality}

Table 5 shows that 30 respondens has mean value for certification is $5.43(\mathrm{SD}=1.569)$ and teacher quality is 141.70 ( $\mathrm{SD}=10.923)$. Coeficient corellation value (r) shows that there are correlation between certification and teacher quality. The increasing of certification, in this case is incentive, will have effect for teacher quality

Table 5. Descriptive Statistics of Certification towards Teacher Quality

\begin{tabular}{lccc}
\hline Variables & Mean & Std. Deviation & N \\
\hline Certification & 5.43 & 1.569 & 30 \\
Teacher Quality & 141.70 & 10.923 & 30 \\
\hline
\end{tabular}


Result from table above shows that there are correlation between certification and teacher quality, with value of $0.5 \%$. That means those correlation quite strong for effect of teacher quality. Certification can give strong impact for teacher quality. Since significance value $0.974>0.05$, then $\mathrm{H}_{\mathrm{O}}$ was rejected and $\mathrm{H}_{\mathrm{a}}$ was accepted. The regression formula is $\mathrm{Y}^{\prime}=\mathrm{a}+\mathrm{b} 1 \mathrm{x} 1$, and $\mathrm{Y}^{\prime}=5.560+0.001 \mathrm{X}_{1}$.

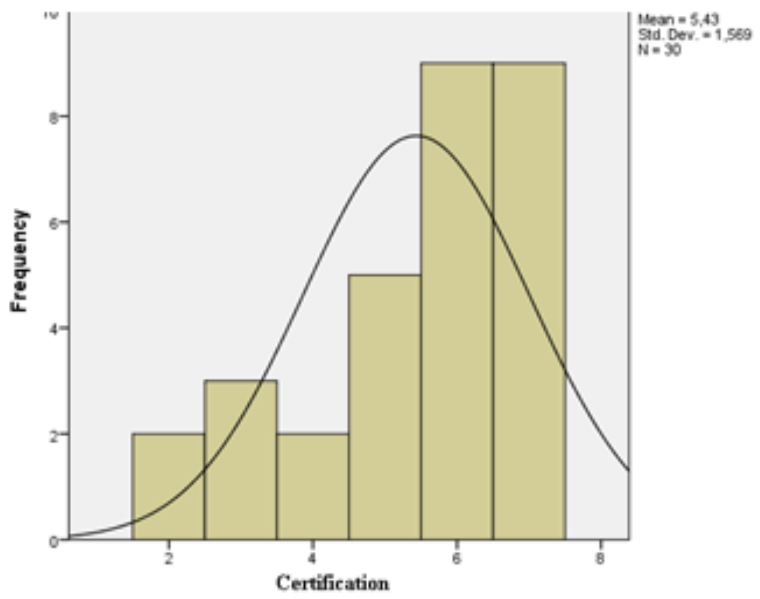

Figure 4. Histogram the effect of certification towards teacher quality

\subsection{The Effect of Competency towards Teacher Quality}

Table 6 shows 30 respondens with mean value for competency is 31.23 ( $\mathrm{SD}=3.645)$ and teacher quality is 141.70 (SD = 10.923). Coeficient corellation value $(\mathrm{r})$ shows that there are correlation between competency and teacher quality. The increasing of competency, in this case performance of teacher, will have effect for teacher quality.

Table 6. Descriptive Statistics of Competency towards Teacher Quality

\begin{tabular}{lccc}
\hline Variables & Mean & Std. Deviation & $\mathrm{N}$ \\
\hline Competency & 31.23 & 3.645 & 30 \\
Teacher Quality & 141.70 & 10.923 & 30 \\
\hline
\end{tabular}

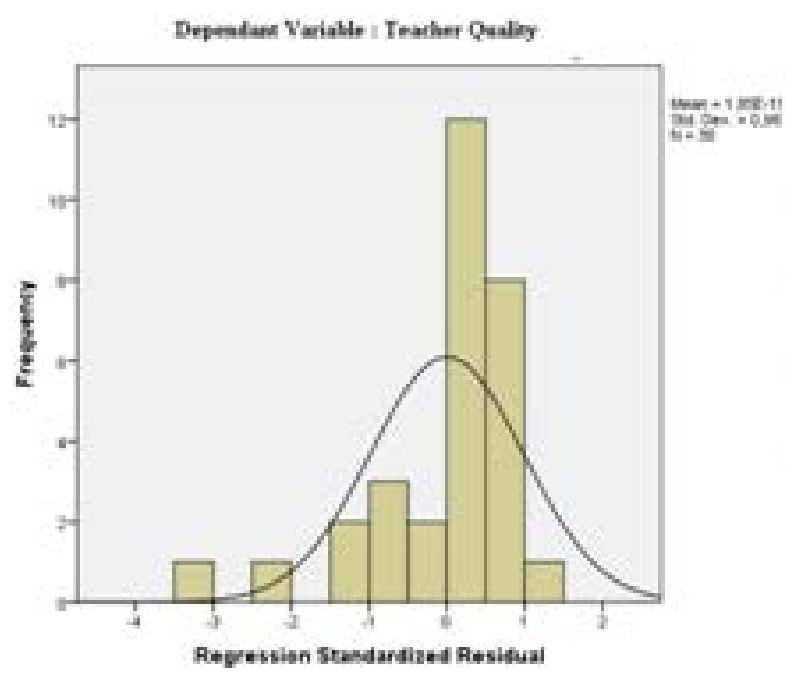

Result from table above shows that there are correlation between competency and teacher quality, with value of $0.5 \%$. That means those correlation is moderate for effect of teacher quality. Competency can give moderate impact for teacher quality. Since significance value is $0.347>$ 0.05 , then $\mathrm{H}_{\mathrm{O}}$ was rejected and $\mathrm{H}_{\mathrm{a}}$ was accepted. The regression formula is $\mathrm{Y}^{\prime}=\mathrm{a}+\mathrm{b} 2 \mathrm{x} 2$, and $\mathrm{Y}^{\prime}=3,383+$ $0,197 \mathrm{X}_{2}$.

Table 7. Coefficient Model

\begin{tabular}{|c|c|c|c|c|c|}
\hline \multicolumn{6}{|c|}{ Coefficients } \\
\hline \multirow{2}{*}{ Model } & \multicolumn{2}{|c|}{$\begin{array}{c}\text { Unstandardized } \\
\text { Coefficients }\end{array}$} & \multirow{2}{*}{$\begin{array}{c}\begin{array}{c}\text { Standardized } \\
\text { Coefficients }\end{array} \\
\text { Beta }\end{array}$} & \multirow[t]{2}{*}{$\mathrm{t}$} & \multirow{2}{*}{ Sig. } \\
\hline & B & Std. Error & & & \\
\hline (Constant) & 3.383 & 7.243 & & 0.467 & 0.644 \\
\hline $\begin{array}{l}\text { Teacher } \\
\text { Quality }\end{array}$ & 0.197 & 0.051 & 0.589 & 3.856 & 0.001 \\
\hline
\end{tabular}

\subsection{The Effect of both Certification and Competency towards Teacher Quality}

Table 8 shows that correlation certification towards teacher quality had value of 0.00 followed by correlation of competency towards teacher quality had value of 0.01 and correlation of both certification and competency towards teacher quality had value of 0.58 .

Table 8. Correlation of Both Variables

\begin{tabular}{|c|c|c|c|c|}
\hline & & Certificatic & ompetency & $\begin{array}{l}\text { Teacher } \\
\text { Quality }\end{array}$ \\
\hline \multirow{3}{*}{ Certification } & $\begin{array}{l}\text { Pearson } \\
\text { Correlation }\end{array}$ & 1 & 0.114 & -0.006 \\
\hline & Sig. (2-tailed) & & 0.547 & 0.974 \\
\hline & $\mathrm{N}$ & 30 & 30 & 30 \\
\hline \multirow{3}{*}{ Competency } & $\begin{array}{l}\text { Pearson } \\
\text { Correlation }\end{array}$ & 0.114 & 1 & $0.589^{* *}$ \\
\hline & Sig. (2-tailed) & 0.547 & & 0.001 \\
\hline & $\mathrm{N}$ & 30 & 30 & 30 \\
\hline \multirow{3}{*}{$\begin{array}{l}\text { Teacher } \\
\text { Quality }\end{array}$} & $\begin{array}{l}\text { Pearson } \\
\text { Correlation }\end{array}$ & -0.006 & $0.589^{* *}$ & 1 \\
\hline & Sig. (2-tailed) & 0.974 & 0.001 & \\
\hline & $\mathrm{N}$ & 30 & 30 & 30 \\
\hline
\end{tabular}

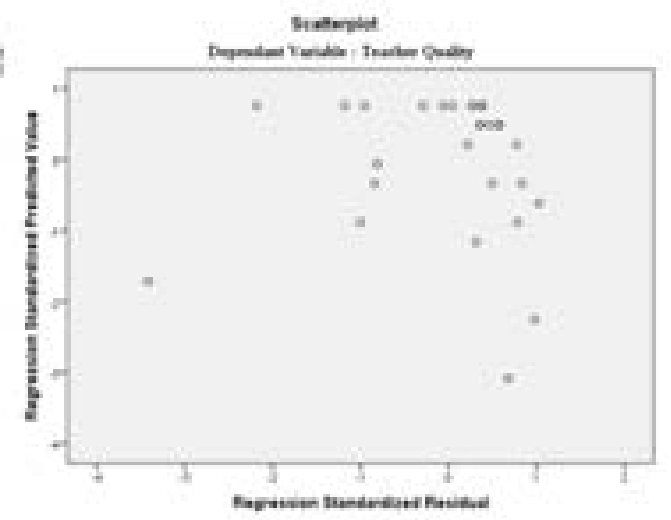

Figure 5. Histogram and Scatterplot for Teacher Quality

Result from interpretation statistic shows that correlation for both certification and competency towards teacher quality had value of 0.594 . Both variable only have effect towards teacher quality of $35.2 \%$. Since significance level $0.001<0.05$, then $\mathrm{H}_{\mathrm{O}}$ was rejected and
$\mathrm{H}_{\mathrm{a}}$ was accepted. The regression formula is $\mathrm{Y}^{\prime}=\mathrm{a}+\mathrm{b}_{1} \mathrm{x}_{1}+$ $\mathrm{b}_{2} \mathrm{X}_{2}$ and $\mathrm{Y}^{\prime}=88.60+0.519 \mathrm{X}_{1}-1.79 \mathrm{X}_{2}$.

When variable of certification is taken out from data, only variable competency has effect towards teacher quality with value of 0.589 (34.7\%). Fit model perfectly 
also shown by LISREL with p-value=1 and RMSEA had significance level $0.00<0.05$.

When using LISREL program, it was found contradictive with previous calculation. It is known that correlation between $\mathrm{X}_{1}$ (certification) and $\mathrm{X}^{2}$ (competency) have no significant, but correlation between $\mathrm{X}_{1}$ (certification) and $\mathrm{Y}$ (teacher quality) have significant. Significance only occurred for $\mathrm{X}_{2}$ (competency) and $\mathrm{Y}$ (teacher quality).

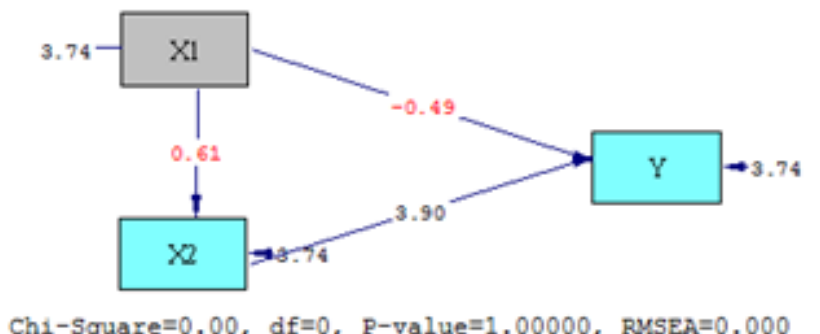

Figure 6. Lisrel of Two Variables X to One Variable Y

\section{Conclusion}

Based on result test of normality and test of linearity, it was shown that all data in this study were valid for analysis. There were positive and significance impact between certification towards teacher quality. The correlation value was $15 \%$. That means, if certification, including incentive payment, increase, there would be increasing in teacher quality. However, there were no positive and no significance effect between competency towards teacher quality. The correlation value was only $0.57 \%$. That means, the teacher quality was not strong influenced by competency. It was only have moderate effect towards teacher quality. Both variables have effect towards teacher quality with value of $34.7 \%$ and significance of $63.1 \%$.

\section{Acknowledgements}

The author would like to thank you to Director General for High Education of Ministy of Education for fully suported and funding this study. Thank you also to MAN 3 Tangerang for object of study and Dean of Faculty of Islamic Studies, University of Muhammadiyah Tangerang, for his support.

\section{References}

[1] Linda Cavvalluzo. Is National Board Certification am Effective Signal of Teacher Quality ?. The CNS Corporation Report. November 2004. Virginia. USA.

[2] Ferguson, R. Teachers' perceptions and expectations and the Black-White test score gap. In C. Jencks and M. Phillips (Eds.), The Black-White Test Score Gap Washington, DC: Brookings Institution Press, 1998, 273-317.

[3] Goldhaber, D. The Mystery of Good Teaching: Surveying the Evidence on Student Achievement and Teachers' Characteristics. Education Next 2 (1) 2002, 50-55.

[4] Goldhaber, D., D. J. Brewer, and D. Anderson. A three-way error components analysis of educational productivity. Education Economics 7(3).1999, 199-208.

[5] Hanushek, E. A., J. F. Kain, and S.G. Rivkin. Do higher salaries buy better teachers? National Bureau of Economic Research Working Paper No. 70, 1999.

[6] Goldhaber, D., D. J. Brewer, and D. Anderson. Does teacher certification matter? High school teacher certification status and student achievement. Educational Evaluation and Policy Analysis 22: 2000, 129-145.

[7] Hanushek, E. A., J. F. Kain, and S.G. Rivkin. The trade-off between child quantity and quality. Journal of Political Economy 100(1)., 1992, 84-117.

[8] Hanushek, E. A.. Assessing the effects of school resources on student performance: An update. Educational Evaluation and Policy Analysis 19:2, 1997, 1411-64.

[9] Hanushek, E. A.. The economics of schooling: Production and efficiency in public schools. Journal of Economic Literature 24(3), 1996, 141-78.

[10] Wright, P., S. Horn, and W. Sanders. Teachers and Classroom Heterogeneity: Their Effects on Educational Outcomes. Journal of Personnel Evaluation in Education 11(1), 1997, 57- 67.

[11] Barro, R.J. Human capital and growth. American Economic Review 91, 2002, $12-17$.

[12] Hall, R.E. and Jones, C.I. Why do some countries produce so much more output per worker than others?, Quarterly Journal of Economics 114, 1999, 83-116.

[13] Johnson, Susan. Merit Pay for Teachers: A Poor Prescription for Reform. Harvard Educational Review 54(2), 1984, 175-85.

[14] Lortie, Dan. Schoolteacher: A Sociological Study. Chicago: University of Chicago Press. 1975.

[15] Goodlad, John. A Place Called School: Prospects for the Future. St.Louis: McGraw-Hill. 1983. 